\title{
Hepatocyte Growth Factor/Scatter Factor Effects on Epithelia \\ Regulation of Intercellular Junctions in Transformed and Nontransformed Cell Lines, Basolateral Polarization of C-met Receptor in Transformed and Natural Intestinal Epithelia, and Induction of Rapid Wound Repair in a Transformed Model Epithelium
}

\author{
Asma Nusrat, * Charles A. Parkos, * Abraham E. Bacarra, * Paul J. Godowski," \\ Charlene Delp-Archer, " Eliot M. Rosen," and James L. Madara * \\ * Division of Gastrointestinal Pathology, Department of Pathology, Brigham and Women's Hospital and Harvard Medical School, \\ Boston, Massachusetts 02115; ${ }^{\ddagger}$ Department of Cell Genetics, Genentech, San Francisco, California 94080; and ${ }^{\S}$ Department of \\ Radiation Oncology, Long Island Jewish Medical Center, New Hyde Park, New York 11042
}

\begin{abstract}
Intestinal epithelial cells rest on a fibroblast sheath. Thus, factors produced by these fibroblasts may influence epithelial function in a paracrine fashion. We examined modulation of intestinal epithelial function by one such fibroblast product, scatter factor/hepatocyte growth factor (HGF /SF). This effect was studied in vitro by using model $\mathrm{T} 84$ intestinal epithelial cells. When applied to confluent T84 monolayers, HGF /SF attenuates transepithelial resistance to passive ion flow in a dose-dependent manner (maximum fall at $300 \mathrm{ng} / \mathrm{ml}, 28 \%$ control monolayer resistance, $P<0.001, \mathrm{ED}_{50}$ of $1.2 \mathrm{nM}$ ), $t_{1 / 2}$ of $20 \mathrm{~h}$. This functional effect of HGF /SF and distribution of its receptor, c-met, are polarized to the basolateral membranes of T84 intestinal epithelial cells. HGF/SF effects on resistance are not attributable to altered transcellular resistance (opening of $\mathrm{Cl}^{-}$and/or basolateral $\mathrm{K}^{+}$channels), cytotoxicity, or enhanced cell proliferation; they therefore represent specific regulation of paracellular tight junction resistance. Analysis with biochemically purified rodent HGF /SF and Madin-Darby canine kidney cells reveals that effects on paracellular tight junctions also occur in other nontransformed epithelia. Binding of HGF / SF to its receptor in T84 intestinal epithelial cells is accompanied by tyrosine phosphorylation of the receptor. Because loosening of intercellular junctions between cells could facilitate separation, spreading, and migration of epithelial cells during physiologic processes such as wound resealing, we determined the effects of HGF/SF on intestinal epithelial wound resealing using our previously published in vitro model (Nusrat, A., C. Delp, and J. L. Madara. 1992. J. Clin. Invest. 89:1501-1511). HGF /SF markedly enhanced wound closure ( $>450 \%$ increase in rate, $P<0.001$ ) by influencing the migratory and spreading response in not only cells adjoining the wound but also cells many positions removed from the wound. We thus speculate that HGF /SF may serve as an important cytokine that influences epithelial parameters such as transepithelial resistance and wound resealing. Further pharmacological approaches to manipulate HGF/SF signaling pathways
\end{abstract}

Address correspondence to Asma Nusrat, M.D., Room 1429 Thorn Building, 20 Shattuck Street, Department of Pathology, Brigham and Women's Hospital, Boston, MA 02115.

Received for publication 27 August 1993 and in revised form 28 January 1994.

J. Clin. Invest.

(C) The American Society for Clinical Investigation, Inc. $0021-9738 / 94 / 05 / 2056 / 10 \$ 2.00$

Volume 93, May 1994, 2056-2065 may provide novel therapeutic strategies to enhance repair of intestinal epithelial erosions/ulcerations. (J. Clin. Invest. 1994. 93:2056-2065.) Key words: epithelial cell motility • restitution • cytokine $\bullet$ intercellular junctions

\section{Introduction}

Exchange of information between mesenchymal and epithelial compartments by paracrine factors influences events as diverse as organ development in embryo genesis and wound repair. For example, scatter factor/hepatocyte growth factor (HGF/ $\mathrm{SF})^{1}(1-3)$ and nerve-derived growth factor (4) represent mesenchymal-derived ligands that influence epithelial growth and/ or morphogenesis via specific epithelial receptors exhibiting tyrosine kinase activity. The potential for such paracrine-mediated mesenchymal-epithelial interactions is particularly relevant to intestinal epithelia. Here, the columnar epithelial monolayer lies in close apposition to a subepithelial fibroblast sheath. Indeed, morphological studies suggest that cell processes may regularly bridge the fine gap separating these mesenchymal and epithelial plates, thus bringing the plasma membranes of these two cell types into direct apposition (5). Thus, it is not surprising that fibroblast products, acting in paracrine fashion, have been shown recently to affect basic roles of intestinal epithelial function such as vectorial ion transport (6). $\mathrm{HGF} / \mathrm{SF}$, a known modulator of epithelial cell function, is secreted by mesenchymal cells such as fibroblasts and represents a candidate paracrine factor that possibly influences intestinal epithelia.

The cytokine HGF/SF has a broad spectrum of activities that includes mitogenic and motogenic effects on epithelial cells. HGF, also known as hepatopoetin A, was first described as a hepatotropic factor present in the serum of rats after partial hepatectomy $(7,8)$ and has also been described in rat platelets (9). HGF is a disulfide-linked heterodimeric protein having significant sequence and domain homology to plasminogen $(10,11)$. SF was characterized originally as a fibroblast- and smooth muscle cell-derived cytokine that "scatters" (i.e., disperses) and stimulates motility of epithelial cells (12-14). It is not known if HGF/SF influences behavior of epithelial monolayers in the tightly confluent state as they exist in nature.

Sequence analysis and cDNA cloning revealed that SF and HGF were indeed identical polypeptides (15-17). Such studies also confirmed the identity of the bioactivities of SF and HGF. For example, recombinant HGF scatters Madin-Darby canine

1. Abbreviations used in this paper: $\mathrm{HGF} / \mathrm{SF}$, hepatocyte growth factor/scatter factor; MD, migration differential; MDCK cells, MadinDarby canine kidney cells. 
kidney (MDCK) cells in culture and induces migration of MDCK cells into collagen gels $(16,17)$, and, conversely, SF stimulates DNA synthesis in hepatocytes. Lastly, HGF and SF are indistinguishable ligands for the receptor encoded by the c-met protooncogene; a $145-\mathrm{kD}$ heterodimeric transmembrane protein that exhibits tyrosine kinase activity (17).

Here, we used model epithelial monolayers $(18,19)$ to provide evidence that intestinal epithelia exhibit polarized distribution of the receptor for SF/HGF. Furthermore, activation of c-met tyrosine kinase activity by SF/HGF is accompanied by modulation of functional parameters in confluent epithelia in a pattern that suggests its regulation of intercellular junctions. In the presence of an epithelial wound, these effects of HGF/SF result in enhanced participation of cells adjoining the wound that spread out and migrate, eventuating in a dramatic increase in the rate of epithelial wound closure.

\section{Methods \\ Cell culture}

The T84 human colonic cell line (20) was grown and passaged as described previously $(20,21)$ and prepared as monolayers on collagencoated polycarbonate supports (22) or, for wounding experiments, on translucent permeable supports of rat tail collagen as detailed previously (23). For studies with purified native mouse SF, MDCK epithelial cells (MDCK, strain II; American Type Culture Collection, Rockville, MD) were grown (24) and prepared as monolayers as described for T84 cells. Because of species restriction, murine $\mathrm{HGF} / \mathrm{SF}$ was used in MDCK cultures and recombinant HGF/SF in T84 cell cultures.

\section{Electrophysiological assays}

Measurements of transepithelial resistance to passive ion flow and short circuit currents were obtained using the voltage clamp approach adapted to the $0.33-\mathrm{cm}^{2}$ microassay as described recently in detail (22). Briefly, apical and basolateral reservoirs were interfaced with $\mathrm{Ag}-\mathrm{AgCl}$ and calomel electrodes via agar bridges, and the potentials evoked with a $25-\mu \mathrm{A}$ current were measured and used to calculate resistances and endogenous electrical currents using Ohm's law. The sieving characteristics of the monolayers were determined by performing unidirectional flux studies in modified Ussing chambers with radiolabeled extracellular markers (mannitol $3.6 \AA$; inulin $11.5 \AA$ ) as described previously (18). Iodine-125 and rubidium-86 efflux rate constants were determined as described in detail elsewhere (25).

\section{Wounds and cellular responses}

Wounds were made in monolayers by removal of a defined disk of cells with aid of suction through a micropipette (beveled tip diameter $0.5-$ $0.6 \mathrm{~mm}$ ) controlled by a micromanipulator as described previously (23). The translucent, permeable supports were constructed to permit direct visualization of responses of epithelial monolayers (23). Monolayers were wounded and allowed to recover in the presence and absence of HGF/SF (diluted in media).

Cells migrating in response to wounding of monolayers were observed visually with the aid of a microscope (Axiovert $35 \mathrm{M}$; Zeiss, Oberkochen, Germany) and a video camera (SIT; Hamamatsu Photonic Systems Corp., Bridgewater, NJ), and were analyzed (DVS-3000; Hamamatsu Photonic Systems Corp.), recorded, and printed (Mitsubishi video cassette recorder and printer). The image analysis system was used to calculate rates of wound closure and analyze the phenotype (area) of cells surrounding the wound. Measurements of wound diameter at the time of injury and at varying time periods thereafter were made. The difference between the two was expressed as the migration differential (MD). The MDs of HGF/SF-exposed and control (HGFunexposed) wounds were compared. Photographs of wounds at the time of injury and at varying periods thereafter were used to quantitate the number of cells at the wound perimeter that were flattened and were participating in the closure process.
Immunofluorescence localization of c-met, E-cadherin, and ZO-1 by confocal microscopy

Intact and resealing T84 monolayers were washed in HBSS (Sigma Immunochemicals, St. Louis, $\mathrm{MO}$ ), fixed in methanol at $0^{\circ} \mathrm{C}$ for 20 min, and incubated with the respective primary antibodies in a humidity chamber. All antibodies were diluted in HBSS containing $0.2 \%$ gelatin and $0.075 \%$ saponin (solution A). Polyclonal antibodies to the $\beta$ chain of c-met were generated (26). Monoclonal antibodies to E-cadherin were purchased from Euro-Diagnostics (Apeldoorn, The Netherlands), and polyclonal antibodies to ZO-1 were kindly provided by $\mathrm{Dr}$. J. Anderson (27). Monolayers that were incubated with the respective primary antibodies for 60 min were washed extensively in solution A. These monolayers were then incubated with FITC-conjugated secondary antibodies (FITC goat anti-rabbit IgG from Organon Teknika Corp. [West Chester, PA] and FITC goat anti-mouse IgG from Boehringer Mannheim Corp. [Indianapolis, IN]) for $60 \mathrm{~min}$. Monolayers rinsed multiple times in solution A were mounted in $\mathrm{PBS} /$ glycerol $/ p$ phenylenediamine solution (1:1:0.01) to preserve the fluorescence.

Fluorescently stained monolayers were analyzed with the aid of a confocal microscope (MRC, 600, Bio Rad; Analytical Instruments Corp., Cambridge, MA) in the $x y$ and $x z$ planes.

Human intestinal tissue was quick frozen in isopentane and dry ice. $5-\mu \mathrm{m}$ frozen sections were immunostained as described for monolayers.

\section{Biochemical studies}

Immunoprecipitation of the c-met receptor and western blotting with phosphotyrosine antibodies. Monolayers were grown on permeable supports $\left(5-\mathrm{cm}^{2}\right.$ polycarbonate rings coated with rat tail collagen). Control monolayers and monolayers exposed to HGF $200 \mathrm{ng} / \mathrm{ml}$ for varying time periods ( $10 \mathrm{~min}-1 \mathrm{~h}$ ) were labeled with biotin following standard protocols $(28)$. T84 monolayers were cooled $\left(4^{\circ} \mathrm{C}\right)$, the media were removed, and monolayers were washed with HBSS. Sulpho$\mathrm{N}$-hydroxysuccinimide ester of biotin (Sulpho-NHS-biotin; Pierce, Rockford, IL) at a concentration of $0.5 \mathrm{mg} / \mathrm{ml}$ was used for the biotinylation reaction. Monolayers were biotinylated for $40 \mathrm{~min}$ at $4^{\circ} \mathrm{C}$, and the reaction was quenched with $50 \mathrm{mM} \mathrm{NH}{ }_{4} \mathrm{Cl}$. Monolayers were washed subsequently with HBSS. To determine the polarity of the cmet receptor, T84 monolayers were selectively biotinylated on the apical or basolateral membranes. Labeled cells were solubilized in lysis buffer ( $50 \mathrm{mM}$ Hepes, $150 \mathrm{mM} \mathrm{NaCl}, 1.5 \mathrm{mM} \mathrm{MgCl}, 1 \mathrm{mM}$ EGTA, $10 \%$ glycerol, $1 \%$ Triton $\mathrm{X}-100,4 \mu \mathrm{g} / \mathrm{ml}$ PMSF, $1 \mu \mathrm{g} / \mathrm{ml}$ aprotinin, and $1 \mathrm{mM}$ Na-orthovanadate) at a density of $1.67 \times 10^{7}$ cells in $500 \mu \mathrm{l}$. Conjugates of protein A-Sepharose CL-4B beads (Sigma Immunochemicals) and anti-MET (polyclonal antibody raised to the $\mathrm{COOH}$ terminus of the $\beta$ chain of c-met) were prepared in an HNTG buffer ( $20 \mathrm{mM}$ Hepes, $150 \mathrm{mM} \mathrm{NaCl}, 10 \%$ glycerol, and $0.1 \%$ Triton X-100). The cell lysates were incubated with the protein A-Sepharose/c-met antibody conjugates ( $500 \mu \mathrm{l}$ of lysates with $50 \mu \mathrm{l}$ of protein A/c-met antibody conjugates) overnight. The resulting immunoprecipitates were denatured by boiling in reducing SDS sample buffer and subjected to SDS-PAGE on $8 \%(\mathrm{wt} / \mathrm{vol}$ ) polyacrylamide gels and subsequently were electrophoretically transferred to nitrocellulose. Biotinylated proteins that were electrophoretically transferred to nitrocellulose sheets were peroxidase labeled with $2 \mathrm{mg} / \mathrm{ml}$ of streptavidin-horseradish peroxidase solution for $1 \mathrm{~h}$ at room temperature (29). To examine tyrosine phosphorylation of the c-met receptor in the control and HGF-exposed samples, the nitrocellulose-transferred proteins were probed with phosphotyrosine antibodies (Upstate Biotechnology Incorporated, Lake Placid, NY), at a dilution of 1:1,000, followed by peroxidase-conjugated secondary antibodies. Peroxidase-conjugated products were visualized with either 4-chloro-1-nephthol (Bio-Rad Laboratories, Richmond, CA) or enhanced chemiluminescence (ECL kit; Amersham International, Buckinghamshire, UK).

Immunoprecipitation of $E$-cadherin and western blotting with phosphotyrosine antibodies. Cell-surface E-cadherin in control and HGF( $200 \mathrm{ng} / \mathrm{ml}$ ) exposed monolayers was immunoprecipitated after biotinylation of T84 monolayers as described above. $1.67 \times 10^{7}$ cells were 
lysed in $500 \mu \mathrm{l}$ of an extraction buffer ( $150 \mathrm{mM} \mathrm{NaCl}, 50 \mathrm{mM}$ Tris, $1 \%$ NP-40, $1 \%$ Triton X-100, $1 \mathrm{mM} \mathrm{CaCl}$, and protease inhibitors as described above for immunoprecipitation of c-met). The sample was precleared with $25 \mu \mathrm{l}$ of Sepharose-protein $\mathrm{G}$ for $1 \mathrm{~h}$ and incubated with $10 \mu \mathrm{l}$ E-cadherin monoclonal antibody (Euro-Diagnostics) for 3 $h$. The sample was incubated with Sepharose-protein $G$ overnight, and the immunoprecipitate was washed and denatured by boiling in reduced SDS sample buffer, subjected to SDS-PAGE on $8 \%$ polyacrylamide gels, transferred to nitrocellulose, and visualized after incubation with peroxidase-conjugated avidin. As detailed above, tyrosine phosphorylation of E-cadherin was detected with phosphotyrosine antibodies.

\section{Proliferation assay}

Control unexposed and HGF/SF-exposed monolayers $(500 \mathrm{ng} / \mathrm{ml}$ for $48 \mathrm{~h})$ were incubated with $\left[{ }^{3} \mathrm{H}\right]$ thymidine $(10 \mu \mathrm{Ci} / \mathrm{ml})$ diluted in media for $6 \mathrm{~h}$. Monolayers were washed and incubated with $0.1 \mathrm{mM}$ cold thymidine for $1 \mathrm{~h}$. Washed cells were solubilized in $0.5 \%$ Triton X-100, and the radioactivity of the samples was determined.

\section{$H G F / S F$}

Mouse SF was purified from culture supernatants from ras oncogenetransformed NIH/2 mouse 3T3 cells (clone D4), as described before (30). Human recombinant HGF was prepared from transfected chinese hamster ovary cells as described previously (26).

\section{Data presentation}

The figures shown are of representative experiments, each of which were repeated as indicated in the legends. To account for monolayerto-monolayer resistance differences within grouped experiments, resistance data were normalized and expressed as percentages of baseline resistance, unless otherwise noted. Data are presented as means \pm SEM of $n$ experiments. The mean values of the different groups were compared by Student's $t$ test.

\section{Results}

$H G F / S F$ modulates cell-cell interactions in confluent epithelial monolayers

$H G F / S F$ attenuates transepithelial resistance in confluent and developing monolayers. T84 cells used in these studies form monolayers with high transepithelial resistance to passive ion flow in the range of $1,100-1,300 \Omega \cdot \mathrm{cm}^{2}$. T84 cells when plated at confluent density take $7 \mathrm{~d}$ to develop a stable high transepi- thelial resistance as described previously (23). To determine if HGF influences functional parameters of monolayers when applied during development of or after attaining electrical confluency, monolayers were exposed to HGF /SF on day 5 (immediately before electrical confluency) or 7 (stable high transepithelial resistance) after plating. Monolayers similarly exposed to vehicle (media) without HGF/SF served as negative controls.

A 48-h exposure of preconfluent or postconfluent monolayers to $\mathrm{HGF} / \mathrm{SF}$ resulted in a dose-dependent decrease in transepithelial resistance (Fig. 1). In both cases, HGF/SF elicited a maximal effect at $300 \mathrm{ng} / \mathrm{ml}(23 \% \pm 3$ and $26 \% \pm 4$ for preand postconfluent monolayers, respectively, vs control, both $P$ $=<0.001)$ and an $\mathrm{ED}_{50}$ of $1.2 \mathrm{nM}$, respectively. As demonstrated in Fig. 2, the HGF/SF effect on transepithelial resistance was detectable within $12 \mathrm{~h}$, but not within $4 \mathrm{~h}$ after adding the cytokine, and reached a maximal value by $48 \mathrm{~h}$.

$H G F / S F$ elicits alterations in transepithelial resistance by modulating the function of intercellular tight junctions. Since the attenuation of transepithelial resistance observed after exposure to $\mathrm{HGF} / \mathrm{SF}$ could result from a variety of processes (cytotoxicity, opening of membrane channels [31], enhanced cell division [ 32] , and modulation of tight junction permeability), experiments were performed to examine each possibility. In response to $\mathrm{HGF} / \mathrm{SF}$ exposure $(500 \mathrm{ng} / \mathrm{ml}, 48 \mathrm{~h})$, lactate dehydrogenase release was unaffected ( $10.3 \mathrm{mOD} / \mathrm{min}$ vs 10.7 $\mathrm{mOD} / \mathrm{min}$ for HGF/SF-exposed vs control, respectively, NS). Similarly, HGF/SF did not appear to affect proliferation of cells in T84 monolayers as judged by $\left[{ }^{3} \mathrm{H}\right]$ thymidine incorporation ( $101 \pm 5 \%$ in HGF-exposed expressed as a percentage of control, NS). Lastly, $\mathrm{K}^{+}$and $\mathrm{Cl}^{-}$channels that are present in T84 cells, when activated, can induce attenuated transepithelial resistance due to altered transcellular resistance (33-35). In this epithelium, such channel activation results in generation of a transepithelial $\mathrm{Cl}^{-}$current that can be detected as a spontaneous short circuit current (21). However, HGF/SF exposure failed to generate such a current across these monolayers in the baseline state. We confirmed these data by measuring the rate constants of efflux for monolayers loaded with the tracers iodine- 125 and rubidium- 86 that are known to ap-

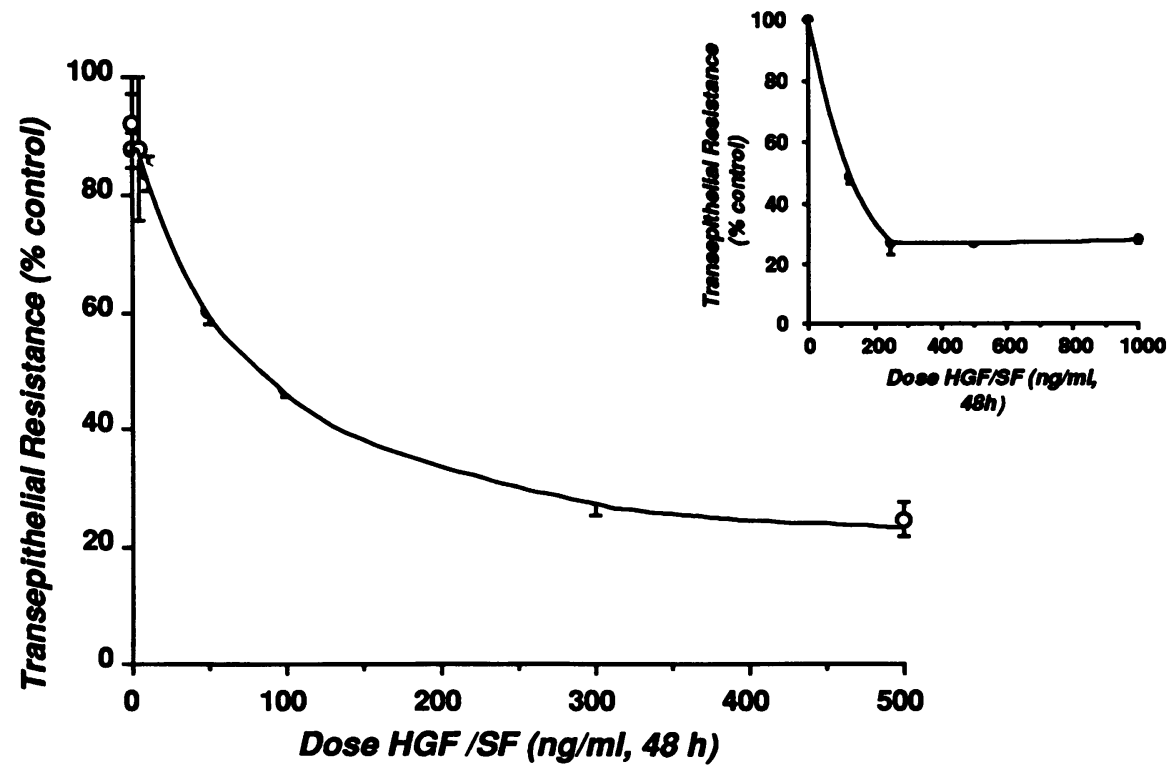

Figure 1. The effects of HGF/SF on transepithelial resistance of T84 monolayers. T84 intestinal epithelial monolayers were exposed to varying concentrations of recombinant HGF/SF on day 5 (main panel) or 7 ( inset) after plating, and transepithelial resistance to passive ion flow was measured $48 \mathrm{~h}$ later. Negative controls included monolayers that were exposed to vehicle (media) only. The transepithelial resistance of the experimental group expressed as a percentage of control (unexposed) monolayers is plotted on the vertical axis, and dose of HGF/SF in nanograms per milliliter is plotted on the horizontal axis. As demonstrated here, HGF/SF attenuates transepithelial resistance to passive ion flow across T84 monolayers in a dose-dependent fashion with maximal attenuation at 300 $\mathrm{ng} / \mathrm{ml}$. Results are presented as the mean \pm SEM of between 10 or 15 monolayers each. 


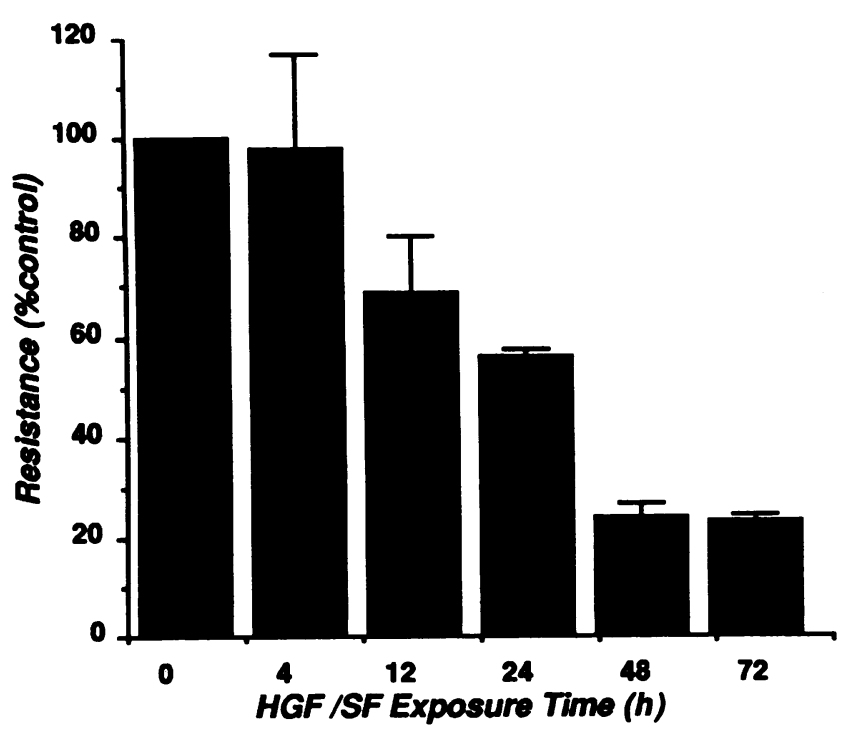

Figure 2. Kinetics of HGF/SF-induced attenuation of transepithelial resistance across T84 monolayers. T84 monolayers were exposed to $500 \mathrm{ng} / \mathrm{ml}$ of $\mathrm{HGF} / \mathrm{SF}$ for varying time periods ranging from 4 to 72 h. Control monolayers were exposed to media (diluting medium for HGF/SF). Transepithelial resistance to passive ion flow in the experimental group expressed as a percentage of control value is plotted on the vertical axis, and HGF/SF exposure time is plotted on the horizontal axis. As shown here, HGF/SF attenuates transepithelial resistance, an effect that is significant within $12 \mathrm{~h}$ of HGF exposure. Data are pooled from five to eight individual monolayers for each condition, and results are expressed as the mean \pm SEM.

propriately probe $\mathrm{K}^{+}$and $\mathrm{Cl}^{-}$channels in $\mathrm{T} 84$ cells (36). Effluxes of these radiolabeled markers were not affected by 300 $\mathrm{ng} / \mathrm{ml}$ of $\mathrm{HGF} / \mathrm{SF}$. The 1-min rate constants of iodine-125 efflux for control vs $\mathrm{HGF} / \mathrm{SF}$-exposed monolayers were $0.185 \pm 0.022$ and $0.177 \pm 0.013$, respectively. The corresponding 1-min rate constants of rubidium- 86 efflux for the control and HGF/SF-exposed monolayers were $0.013 \pm 0.001$ and $0.010 \pm 0.001$, respectively.

Monolayer and epithelial cell integrity were assessed by measuring electrical responses that require sustained activation of the major ion transport pathway in T84 cells, electrogenic $\mathrm{Cl}^{-}$secretion. Short circuit current responses to forskolin $\left(10^{-6}\right.$ $\mathrm{M})$, an activator of cAMP-mediated $\mathrm{Cl}^{-}$secretion, were unaffected by HGF/SF ( $500 \mathrm{ng} / \mathrm{ml}, 48 \mathrm{~h})(69.76 \pm 2.3$ vs $69 \pm 1.4$ $\mu \mathrm{A} / \mathrm{cm}^{2}$ for peak current, control vs HGF, respectively, NS).

Functional integrity of T84 intestinal epithelial monolayers is not modulated by $H G F / S F$. The above findings suggest that the decreases in transepithelial resistance observed were specifcally due to altered cell-cell interactions with resulting changes in the rate-limiting resistance barrier in the paracellular pathway, the intercellular tight junction. Given the relationship between alterations in junctional resistance and junctional sieving of inert hydrophilic molecules (18), transepithelial flux of such solutes would only be expected to change marginally for the end resistances observed with HGF/SF that are in excess of $280 \Omega \cdot \mathrm{cm}^{2}$ (resistances in response to $500 \mathrm{ng} \mathrm{HGF}, 48 \mathrm{~h}$ average $285 \pm 23$ vs $1,250 \pm 50 \Omega \cdot \mathrm{cm}^{2}$ for HGF vs control). As expected, fluxes of $\left[{ }^{3} \mathrm{H}\right]$ mannitol and $\left[{ }^{14} \mathrm{C}\right]$ inulin were affected only marginally by $\mathrm{HGF} / \mathrm{SF}$. The $\left[{ }^{3} \mathrm{H}\right]$ mannitol flux across monolayers in control vs $\mathrm{HGF} / \mathrm{SF}$ was $85.6 \pm 3.7$ and $105 \pm 9$

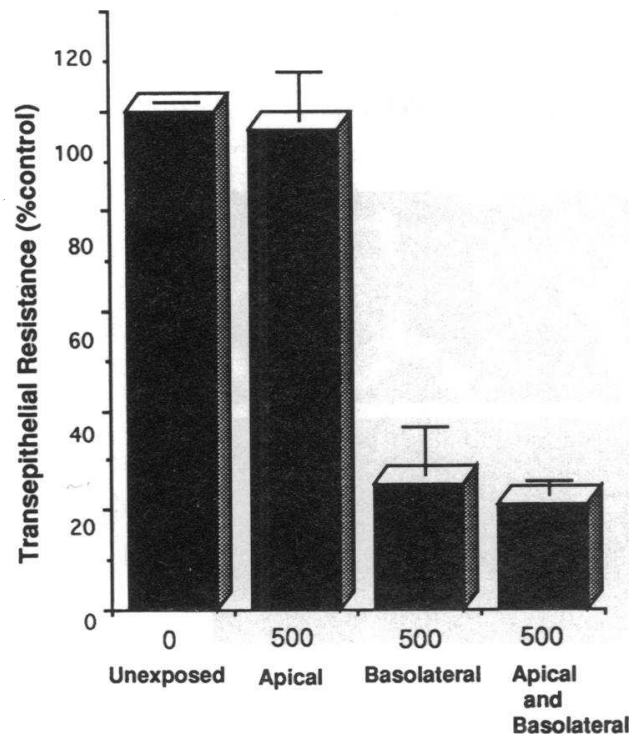

Figure 3. Effects of apical vs basolateral exposure of T84 monolayers to $500 \mathrm{ng} / \mathrm{ml}$ of HGF/SF. The apical, basolateral, or both surfaces of T84 epithelial monolayers were exposed to HGF/SF. Transepithelial resistance to passive ion flow across these monolayers was measured $48 \mathrm{~h}$ later and is expressed as a percentage of resistance in control monolayers exposed to media only. Like unexposed controls, monolayers exposed to $500 \mathrm{ng} / \mathrm{ml}$ of HGF/SF in the apical compartment maintain high resistance. In contrast, monolayers exposed to basolateral HGF/SF exhibit a major fall in resistance that is not further attenuated with simultaneous apical exposure. Data are pooled from six to nine individual monolayers for each condition.

$\mathrm{nmol} \cdot \mathrm{h}^{-1} \cdot \mathrm{cm}^{-2}$, respectively. The corresponding $\left[{ }^{14} \mathrm{C}\right]$ inulin flux across these monolayers was $9.3 \pm 3$ and $13.2 \pm 0.5$ $\mathrm{nmol} \cdot \mathrm{h}^{-1} \cdot \mathrm{cm}^{-2}$, respectively, for control vs $\mathrm{HGF} / \mathrm{SF}-\mathrm{ex}-$ posed monolayers. Such findings also substantiate that monolayer integrity is preserved under conditions associated with HGF effects on intercellular junctions. Moreover, as mentioned above, lack of any difference in electrogenic $\mathrm{Cl}^{-}$secretion in control and HGF-exposed monolayers further substantiates monolayer integrity.

\section{The $H G F / S F$ functional response and the $H G F / S F$ receptor are basolaterally polarized}

Polarity of HGF/SF functional response. As shown in Fig. 3, attenuated transepithelial resistance in T84 monolayers induced by HGF required basolateral exposure to the cytokine. Maximal effects could be achieved by addition of HGF/SF to the basolateral chamber alone (transepithelial resistance and standard error for control, apical, and basolateral were $1,065 \pm 28,1,129 \pm 30$, and $417 \pm 19 \Omega \cdot \mathrm{cm}^{2}, P<0.001$, respectively).

Distribution of the $H G F / S F$ receptor, c-met, in T84 intestinal epithelial cells. As expected and shown in Fig. $4 \mathrm{~A}$, the antibody for the $\beta$ chain of c-met protooncogene product immunoprecipitates a $145-\mathrm{kD}$ protein under reducing conditions. As also shown in Fig. $4 A$, c-met is labeled by selective basolateral $(B l)$, but not apical $(A p)$, biotinylation. Detection by immunofluorescence and analysis by confocal microscopy was used to further define the polarity and distribution of the c-met protooncogene protein product in T84 crypt epithelial cells. The photomicrograph in Fig. $4 B$ represents an en face image of 

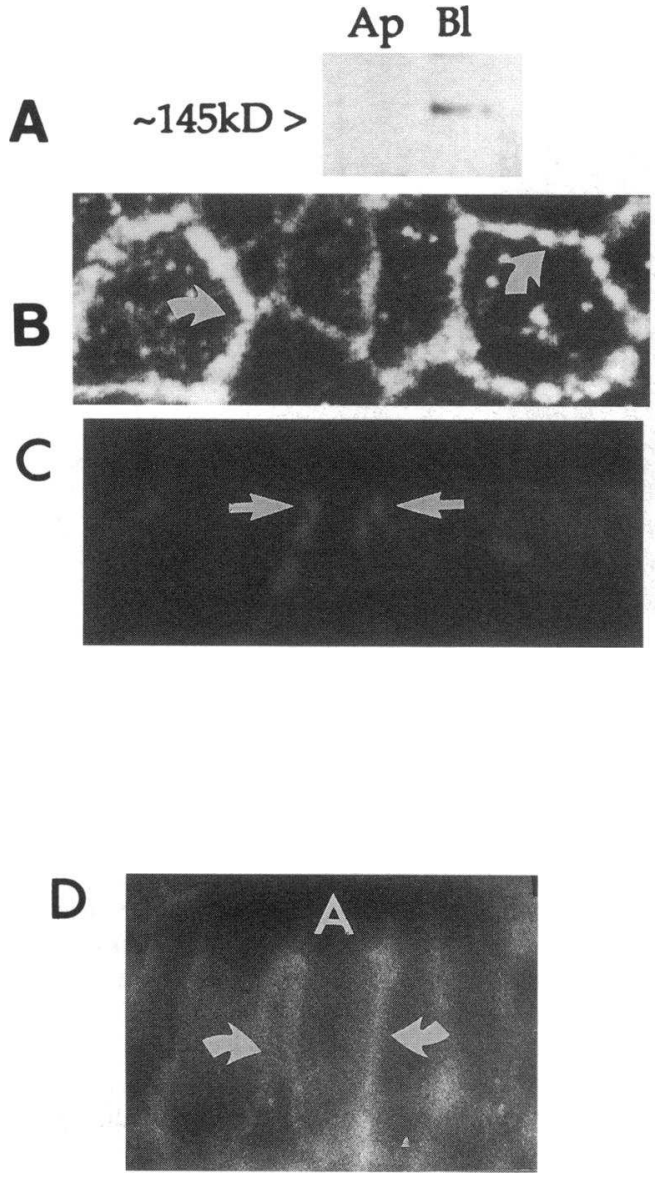

Figure 4. Polarity of c-met in T84 cells. $A$ demonstrates results of cmet immunoprecipitation studies in T84 epithelial monolayers using high affinity antibodies to the carboxy terminal of the $\beta$ chain of cmet. Confluent monolayers were selectively biotinylated on either the apical or basolateral membranes. As shown in this panel, a biotinylated $145-\mathrm{kD}$ protein corresponding to the molecular mass of c-met is immunoprecipitated from the basolateral $(B l)$ but not the apical $(A p)$ membranes of T84 cells. $B$ and $C$ reveal immunofluorescent confocal images of the c-met receptor. $B$ demonstrates an en face image of a confluent T84 monolayer demonstrating perijunctional/basolateral staining of c-met (arrows). $C$ reveals basolateral staining of c-met in a reconstructed confocal image taken in the $x z$ plane. This photomicrograph demonstrates strong labeling of the basolateral membranes of T84 cells (arrows) and not the apical membranes. $D$ demonstrates basolateral distribution of c-met in native intestinal crypt epithelial cells (arrows). Frozen sections of the native intestine were immunostained with antibodies to c-met. The apical membrane of the crypt epithelium is marked as A.

a T84 monolayer at the level just below the junctional complex stained with antibodies to the $\beta$ chain of the HGF/SF receptor and highlights the basolateral staining of c-met. The selective basolateral distribution of c-met is confirmed on xz-axis-reconstructed confocal images as shown in Fig. $4 C$.

Distribution of the $H G F / S F$ receptor, $c$-met, in the native human intestine. The distribution of the c-met protooncogene product was then determined in the native human intestine. Frozen sections of the native human intestine immunostained with antibodies to c-met (as described above) revealed basolateral distribution of the receptor in crypt epithelial cells. This is demonstrated by the arrows in Fig. $4 D$.

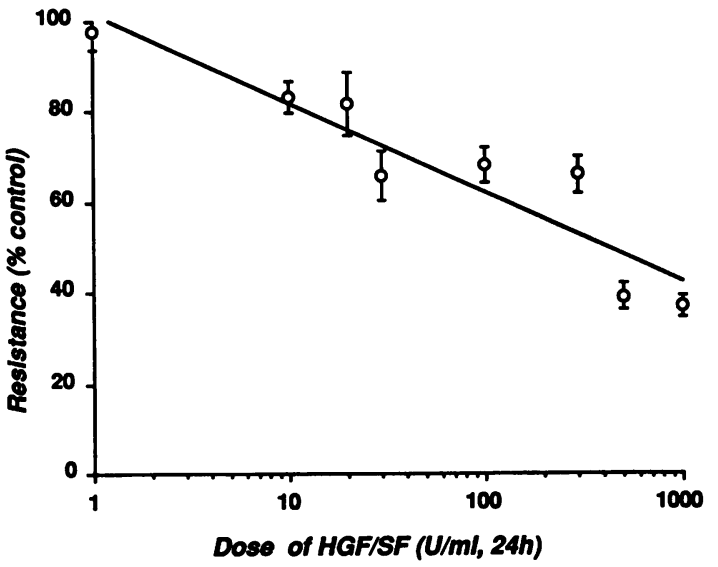

Figure 5. Attenuation of transepithelial resistance across MDCK monolayers after exposure to purified murine HGF/SF. The dose response of HGF/SF on MDCK cell monolayer transepithelial resistance to passive ion flow was measured. Resistance was taken $24 \mathrm{~h}$ after plating MDCK cells in the presence (experimental) and absence (control) of HGF/SF. Monolayer resistance of the experimental group is expressed as a percentage of control resistance ( $y$-axis). $\mathrm{HGF} / \mathrm{SF}$ dose in Units per milliliter is plotted on a log scale ( $\mathrm{x}$-axis). As demonstrated here, $\mathrm{HGF} / \mathrm{SF}$ attenuates transepithelial resistance across MDCK monolayers in a dose-dependent fashion. Results are the mean \pm SEM of between 8 and 10 monolayers each.

The effects of HGF /SF on cell-cell contacts as reflected by altered paracellular resistance occurs in MDCK monolayers as well

We next examined the effects of HGF/SF across other species and cell types. We thus determined the influence of purified murine HGF/SF on transepithelial resistance of the well defined nontransformed canine model epithelium of renal origin, MDCK. As shown in Fig. 5 and analogous to human HGF/SF effects on T84 monolayers, murine HGF/SF exposure results in attenuated transepithelial resistance across confluent MDCK monolayers. This effect occurred in a dose-dependent fashion. $500 \mathrm{U} / \mathrm{ml}$ of murine $\mathrm{HGF} / \mathrm{SF}$ induces maximal attenuation of transepithelial resistance (HGF/SF resistance as a percentage of control monolayer resistance, $36 \pm 6 \%, P$ $<0.001)$. Significant attenuation of MDCK transepithelial resistance in response to murine HGF/SF was observed within 6 h of exposure (Fig. 6). As in human HGF/SF-exposed T84 monolayers, the polarity of murine HGF/SF biophysical response in MDCK cells was found to be basolaterally polarized. Such results demonstrate a conservation of the functional transepithelial resistance response induced by HGF/SF across not only different species but between transformed and nontransformed cell lines originating from intestine and kidney, respectively.

$H G F / S F$ induces tyrosine phosphorylation of the c-met receptor in $T 84$ monolayers, but does not alter E-cadherin or Z0-1 distribution or surface expression in intestinal epithelia

Tyrosine phosphorylation of the c-met receptor. Having shown that intestinal T84 epithelial cells express the c-met receptor polarized to basolateral membranes, a position optimal for interaction of epithelial cells with underlying mesenchymal cells such as fibroblasts, we next determined the activation of c-met tyrosine kinase activity after binding of $\mathrm{HGF} / \mathrm{SF}$ to its receptor 


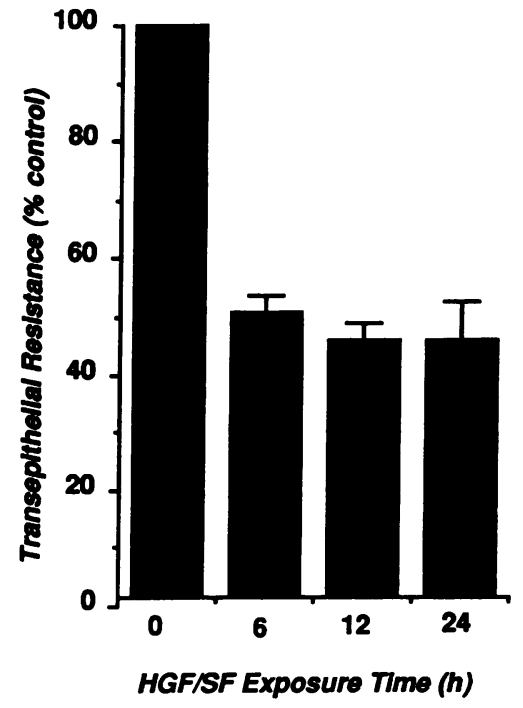

transepithelial resis-

tance, an effect marked at $6 \mathrm{~h}$ after exposure to HGF/SF. Data presented here are the pooled results of 6-10 monolayers for each time point.

in our model system. Fig. 7 shows results of immunoprecipitation of c-met using antibodies to the $145-\mathrm{kD} \beta$ chain from control (media only, lane $C$ ) and HGF/SF-exposed (200 ng/ $\mathrm{ml}$ for $15 \mathrm{~min}$, lane $S F / H G F$ ) monolayers. Western blots were subsequently probed with phosphotyrosine antibodies. These blots reveal no detectable tyrosine phosphorylation of c-met in the baseline unstimulated state. However, binding of HGF/SF to its receptor is followed by tyrosine phosphorylation of the receptor as demonstrated by labeling of the $145-\mathrm{kD}$ band with phosphotyrosine antibodies. The nature of the $100-\mathrm{kD}$ band in both the lanes is unclear, and future experiments will be undertaken to address this issue.

Distribution of the junctional proteins, E-cadherin, and ZO-1 in T84 cells exposed to HGF/SF. E-cadherin appears to represent a critical basolateral surface adhesion molecule that likely contributes substantial force to cell-cell interactions and assists in assembly of other junctions as well as the basolateral membrane cytoskeletal cortex $(37,38)$. E-cadherin and ZO-1 distribution in control T84 monolayers and monolayers exposed to $200-500 \mathrm{ng} / \mathrm{ml}$ of $\mathrm{HGF} / \mathrm{SF}$ for $48 \mathrm{~h}$ were examined by immunofluorescence staining. As represented in the en face images of Fig. 8, the distribution or staining intensities of $\mathrm{E}$ cadherin ( $A$ and $B$ ) or ZO-1 ( $C$ and $D$ ) were similar in control and $\mathrm{HGF} / \mathrm{SF}$-exposed monolayers.

We next sought to determine if HGF/SF exposure altered surface expression of E-cadherin by immunoprecipitation of E-cadherin from monolayers that were selectively biotinylated on the apical or basolateral membranes. As shown in Fig. 8 (inset), HGF/SF exposure $(300 \mathrm{ng} / \mathrm{ml}$ ) did not alter the intensity of the $120-\mathrm{kD}$ band, a finding that was supported by densitometry. Similar results were obtained in MDCK cells exposed to purified SF. In the latter case, we also determined surface expression of E-cadherin by assaying for trypsin-induced release of the $80-\mathrm{kD}$ E-cadherin fragment (37) as a function of HGF/SF exposure. Analogous to human HGF/SF effects in the T84 cell model, murine HGF/SF did not appear to alter cell-surface availability of E-cadherin using this assay (data not shown).

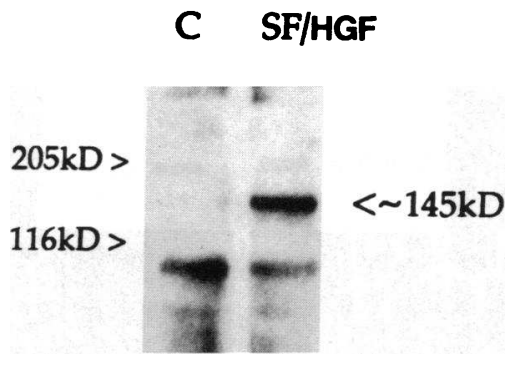

Figure 7. Tyrosine phosphorylation of cmet in $\mathrm{T} 84$ cells after incubation with HGF/ SF. This figure shows the result of immunoprecipitation of c-met from control monolayers (lane $C$ ) and from monolayers exposed to $\mathrm{HGF} / \mathrm{SF}$ at $200 \mathrm{ng} / \mathrm{ml}$ for $15 \mathrm{~min}$

(lane $S F / H G F$ ). The Western blots probed with phosphotyrosine antibodies reveal no detectable tyrosine phosphorylation of c-met in the baseline unstimulated state (lane $C$ ). However, binding of HGF/ $\mathrm{SF}$ to its receptor is followed by phosphorylation of the receptor as demonstrated by labeling of the $145-\mathrm{kD}$ band (lane $S F / H G F$ ) with phosphotyrosine antibodies.

\section{Contributions of HGF/SF downregulated cell-cell associations to wound healing in the intestinal epithelial monolayer}

Rapid reepithelialization of wounds in columnar epithelia occurs by migration of cells into the denuded area $(39,40)$. Such an event would potentially be constrained by the maintenance of substantial junctional contacts and thus could be assisted by HGF/SF effects on these contacts. We next tested this hypothesis by applying HGF/SF to wounds made in T84 monolayers grown on translucent collagen supports using our previously characterized model (23). As examined quantitatively by MD (the difference in wound diameter at the time of injury vs $20 \mathrm{~h}$ later) in Fig. 9 and exemplified in Fig. 10, wounds exposed to $300 \mathrm{ng} / \mathrm{ml}$ of HGF/SF for $20 \mathrm{~h}$ recovered an average of $5 \pm 1.03$ times faster than control unexposed wounds $(P<0.001)$. Analogous wound closure was obtained after exposure to $200 \mathrm{ng} / \mathrm{ml}$ of HGF/SF, but dropped off to 1.5 times the control values at $100 \mathrm{ng} / \mathrm{ml}$ of HGF $(P<0.001)$. Not only did these wounds in T84 monolayers reseal significantly faster than control wounds, but the perimeter of cells surrounding the wound that spread out and thus participate in this closure event also markedly increased after HGF/SF exposure (Figs. $9 B$ and 10 ). Quantitation of numbers of cell perimeters adjacent to the wound edge that participate in this spreading event revealed that $\mathrm{HGF} / \mathrm{SF}$ exposure increased the participation of spreading cell perimeters by $320 \%$ (Figs. 9 and 10$)(P<0.001)$.

\section{Discussion}

We demonstrate that HGF/SF exerts effects on a functional parameter relating to cell-cell contacts in confluent epithelia. Thus, in addition to the effects of this cytokine on developing epithelia and subconfluent epithelia, modulatory effects on confluent, mature epithelia may occur. Since these observations were obtained from human and canine epithelia of intestine and renal origin, respectively, $\mathrm{HGF} / \mathrm{SF}$ effects are likely to be conserved across different epithelia and species. However, studies we report focus primarily on HGF/SF effects in intestinal epithelia.

$H G F / S F$ effects on cell-cell contacts as detected by electrical assays. Although the electrical assay of transepithelial resistance is commonly used by cell biologists as an assay of tight junction permeability (18), it is clear that this assay can be 

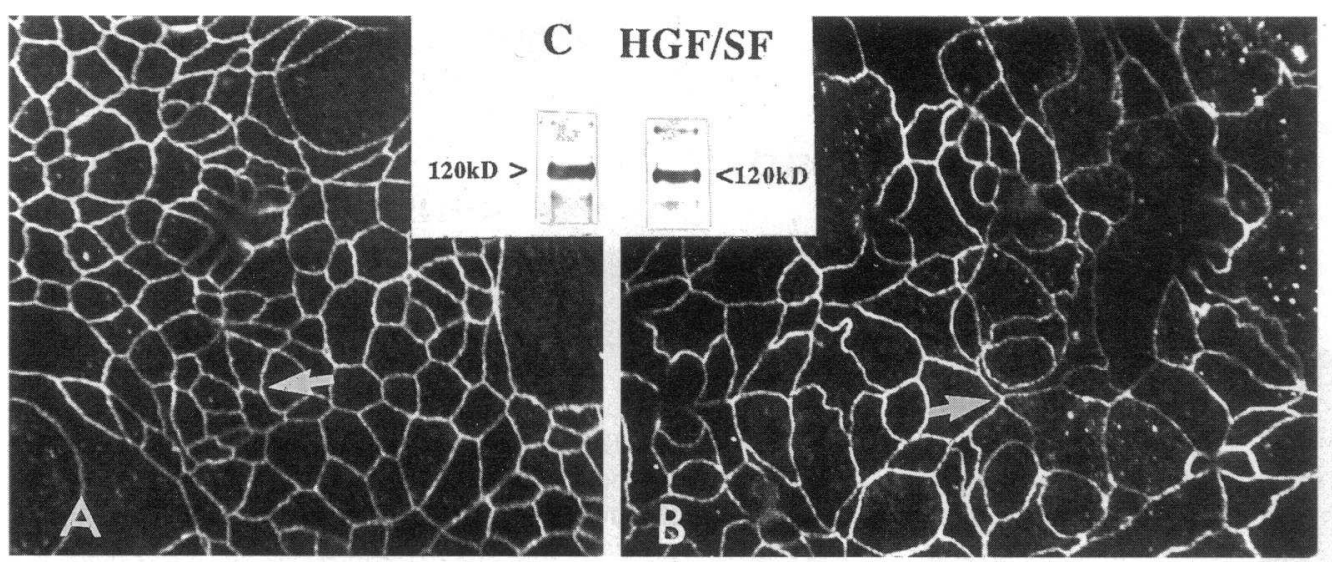

Figure 8. Distribution of the junctional proteins, E-cadherin, and ZO-1 in T84 cells exposed to $200-500 \mathrm{ng} / \mathrm{ml}$ of HGF/SF. E-cadherin and ZO-1 distribution in T84 monolayers exposed to HGF/SF for $48 \mathrm{~h}$ and control unexposed monolayers were analyzed by confocal microscopy after staining with their respective primary antibodies and FITC-conjugated secondary antibodies.

All photomicrographs represent en face images of monolayers. $A$ and $B$ reveal peri-
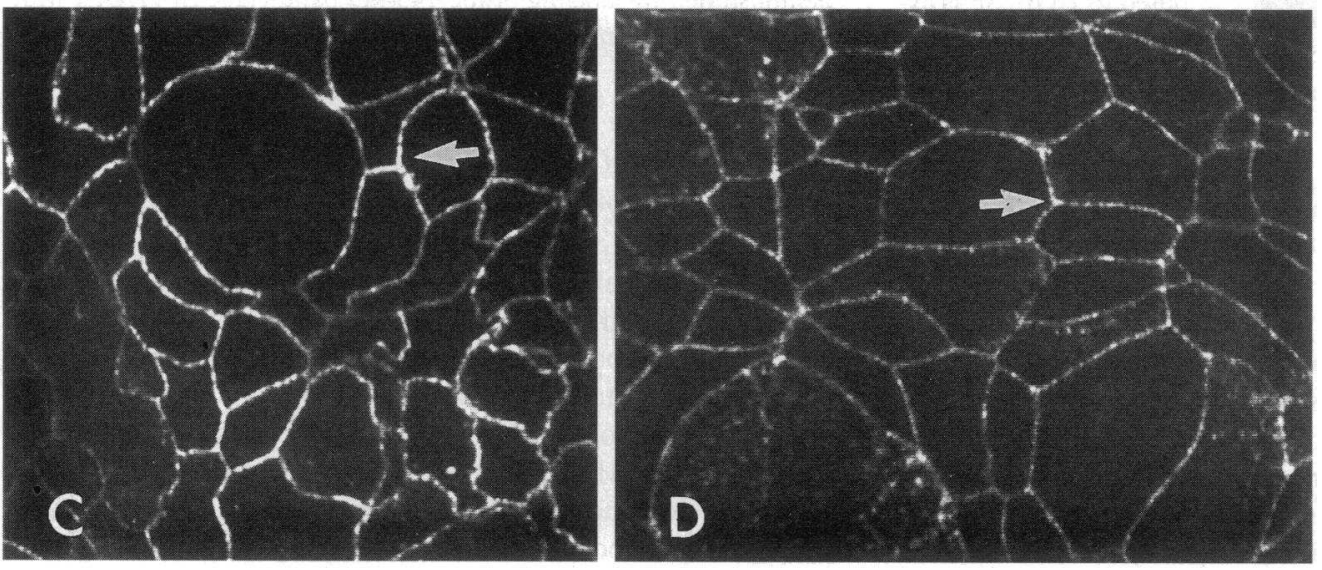
junctional ringlike distribution of E-cadherin (arrows) in control and HGF/SF-exposed monolayers, respectively. No difference in staining pattern was observed. Similarly, $C$ and $D$ reveal a ringlike basolateral pattern of staining for ZO-1 (arrows) with no difference in the two groups. The inset shows surface expression of E-cadherin in T84 monolayers exposed to HGF/SF. T84 monolayers were exposed to $300 \mathrm{ng} / \mathrm{ml}$ of $\mathrm{HGF} / \mathrm{SF}$, and the surface distribution of E-cadherin was analyzed after biotinylation of cell-surface proteins followed by immunoprecipitation and Western blotting of E-cadherin. Biotinylated and immunoprecipitated E-cadherin were detected after incubating the blots with HRP-conjugated avidin and detection with ECL. Results were compared with monolayers incubated with media only and analyzed in a parallel fashion. Densitometry of the band at $120 \mathrm{kD}$ revealed no significant difference in the two groups.

influenced by diverse events such as cell lysis and even physiologically regulated opening of channels on apical and basolateral membranes of epithelial cells ( 31 ). However, once supplementary data have ruled out other such possibilities, this assay is generally a reasonable one for detecting alterations in passive ion flow through the paracellular pathway for which the tight junction is rate limiting. Such use of this assay takes a view of the epithelium in which paracellular pathways essentially represent individual resistors in parallel circuit. Thus, as is well known, the reciprocal of the total resistance across this circuit will equal the sum of the reciprocals of the individual resistors. The resistance assay is thus highly skewed toward detection of resistances within the circuit which are low relative to others. At high resistance values, such as those seen in T84 monolayers, such skewing provides for extremely sensitive detection of even minor alterations in passive paracellular ion flow. Thus, as shown previously (18) and as exemplified by the current data, perturbations in paracellular pathways small enough to yield barely detectable changes in flux of inert solutes and no alterations in ZO-1 distribution can, in high resistance monolayers, yield easily detectable resistance signals. This fact makes this assay useful in screening for general aspects of cell-cell associations. For example, although as discussed above, the tight junction is rate limiting to passive ion flow through the paracellular space, the ability of this junction to act as such a seal appears to be sensitive to more general features of cell-cell interactions. For example, if E-cadherinmediated homeotypic interactions between neighboring epithelial cells are disrupted, the tight junction barrier secondarily disassembles (38). Thus it is likely that, while the tight junction is a crucial permeability barrier because of its continuous circumferential nature and the close membrane-membrane apposition that occurs between neighboring cells at this site, it may not contribute substantially to force interactions between cells. Indeed, such characteristics would be advantageous and would serve to enhance the ability of cells to reversibly regulate the structural and permeability characteristics of this junction; such has been shown to be the case in different epithelia.

Given the potential usefulness of the resistance assay in screening for general alterations in cell-cell associations, we used this assay to probe whether HGF/SF modulates junctional contacts in confluent epithelia since it is known to modulate such intercellular contacts in the periphery of colonies in subconfluent epithelia $(13,41,42)$. Since E-cadherin plays a central role in cell-cell associations and in the putative initiation of the basolateral cytoskeletal cortex assembly $(27,43)$, we determined if the surface distribution or surface expression of this protein was altered by HGF/SF. It appeared not to be the case. We have looked at earlier time points and have not been able to observe altered distribution or expression of E-cadherin 

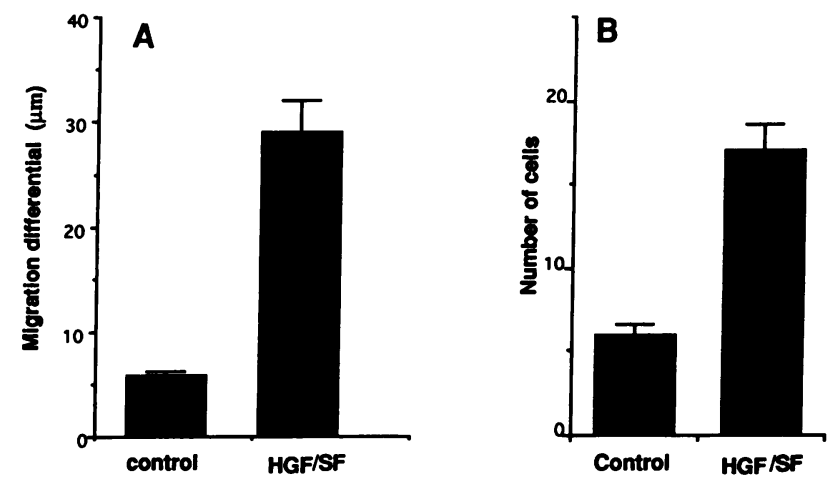

Figure 9. Migration of T84 cells in wounds exposed to HGF/SF. Regulated wounds were made in T84 monolayers by removing a disk of cells from the collagen membrane. The diameter of the wound was measured with an image analysis system, and photographs were taken. $200 \mathrm{ng} / \mathrm{ml}$ of HGF/SF was added to the wounds in the experimental group. Control monolayers were incubated with media only. $20 \mathrm{~h}$ later, the diameters of resealing wounds were measured, and photographs were taken. $A$, shows the migration differential, which represents the decrease in wound diameter in $\mathrm{HGF} / \mathrm{SF}$-exposed and control monolayers. As evident here, enhanced efficiency of wound closure occurs after HGF/SF exposure. $(B)$ This graph represents the number of cells adjoining the wound that exhibit features of migration, i.e., they are flattened out and have spread morphology. This perimeter of cells in HGF/SF-exposed monolayers is markedly increased.

in response to HGF/SF. These observations, paired with those of Weidner et al. (14), suggest that the HGF/SF effects may not directly involve E-cadherin. These investigators used subconfluent monolayers to analyze the expression and phosphorylation of E-cadherin in response to HGF/SF and were unable to demonstrate HGF-induced alterations in such parameters. Although E-cadherin appears to play a central role in cell-cell associations in columnar epithelia, it is still possible however that $\mathrm{HGF} / \mathrm{SF}$ affects E-cadherin indirectly through effects on potential E-cadherin regulators, such as the recently described $\alpha$ - and $\beta$-catinins (44).

Anatomic considerations of $H G F / S F$ effects on confluent intestinal epithelia. Many columnar epithelia exhibit an enriched area of tight apposition with mesenchymal cells baso- laterally. In the intestine, this is exemplified not only by the fibroblast sheath which lies immediately below the epithelial monolayer, but also by the foci of direct contact between epithelial and fibroblast plasma membranes that have been described at this site (5). Coculture experiments have recently shown that such proximity can facilitate signaling exchange between these cell types such as eicosanoid signaling from fibroblasts to intestinal epithelia, which results in modulated ion transport (6). We find that the receptor for HGF, the c-met protooncogene product (45), is polarized to the basolateral membrane of T84 cells. Such basolateral location of the receptor in intestinal epithelial cells would be required for recognition of fibroblastderived paracrine factors. We also demonstrate tyrosine phosphorylation of c-met that has been correlated with activation of the c-met receptor (45) after binding of its ligand in our model intestinal epithelial cells. It is difficult at present to relate the observed functional alterations elicited by HGF to the tyrosine kinase activity of its receptor. The cascade linking receptor activation to the alterations in resistance (or to scattering in subconfluent cells) is likely to be complex as they are not closely related temporally (activation of kinase within minutes but functional effects only after several hours). Biophysical studies using MDCK cells and SF support the basolateral polarity of the HGF response in T84 cells. In contrast, Tsarfaty et al. (46) have reported an apical distribution of the met protooncogene receptor in day 11 embryonic mouse alimentary tract. c-met localizes to the basolateral plasma membrane in our system since biotin labeling at $4^{\circ} \mathrm{C}$ would not have access to the subplasma membrane pool. Given the diffuse apical staining pattern shown by the authors, it is uncertain if this difference relates to the species, developmental stage, or even the presence of nonsurface cytoplasmic pool in the embryo. Sonnenberg et al. (47) have elegantly demonstrated the expression patterns of HGF/SF and its receptor during mouse development. They observed transcripts of c-met in epithelial cells of various organs and ligand expression in adjoining mesenchymal cells, an expression pattern ideal for the interaction of epithelial cells with factors produced by the adjoining mesenchyme. In an analogous fashion, the basolateral expression of c-met in the native intestine that we report here would place it in an optimal location to interact with factors produced by the underlying mesenchyme-derived cells. Moreover, Sonnenberg et al. (47)
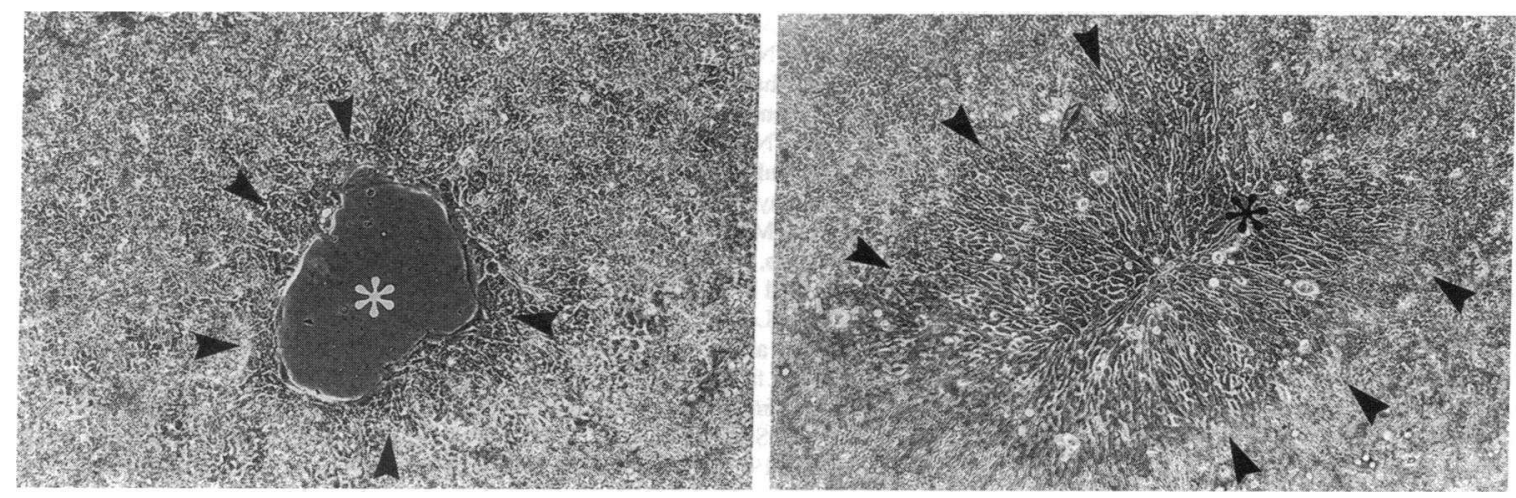

Figure 10. Influence of HGF/SF on resealing of wounds in T84 monolayers. Equivalent wounds were made $20 \mathrm{~h}$ before this photograph using suction through pipettes controlled by micromanipulators. The wound (asterisk) in the left panel recovered in media and is not resealed as yet. In contrast, equivalent $\mathrm{HGF} / \mathrm{SF}$ ( $200 \mathrm{ng} / \mathrm{ml}$ )-exposed wounds have resealed (right panel). Such wounds exposed to HGF recovered five times faster than control unexposed wounds. Note the enlarged perimeter of cells surrounding the HGF/SF-exposed wound (arrowheads) compared with control wounds. Cells in this perimeter exhibit flattened phenotype (with wider intercellular spaces) and are participating in the migration process. 
observed dynamic changes in the expression of HGF/SF during morphologic reorganization and differentiation of the intestinal epithelium. They postulate that the expression of HGF/SF in patches of mesenchyme is associated with cells invading the epithelium and is most likely associated with loosening of the epithelial cell layer in the intestinal anlagen. HGF/SF may play a similar role during events such as wound healing.

$H G F / S F$ promotes epithelial wound resealing in $T 84$ monolayers. Only relatively recently has it been appreciated that epithelial wounds creating superficial and small discontinuities in the monolayer heal too quickly to be explained by enhanced cell turnover. For example, if a disk of cells 30-cell positions wide is removed from the surface of the natural intestinal mucosa, the epithelium is fully resealed, functionally as well as morphologically, within $45 \mathrm{~min}$ (40). Such events can be recapitulated in model epithelia such as T84 monolayers (23). This process of rapid resealing, termed epithelial restitution, represents the flattening of columnar cells bordering the wound by the extension of lamellipodia and filopodia into the denuded site $(23,39,40,48)$. If the wounds are exceedingly small, such events can be aided additionally by development of a sphincterlike actin-myosin II ring which extends through the cells around the wound perimeter (49). While the phenotype of migration in these perimeter cells is generally similar to that in more professionally migrating cell types such as macrophages and neutrophils $(50,51)$, the migration of columnar epithelia does exhibit one major difference. In contrast to neutrophils, macrophages, and the like that may migrate as independent agents, the borders of the migrating epithelial cells removed from the wound edge retain intercellular junctional contacts. It is likely that such rearward contacts constrain the ability of these cells to migrate into wounds, effects that could be related either directly to cell-cell adhesive interactions or indirectly to the cortical organization signals likely conferred by such adhesive interactions. It appears that modulations of intercellular contacts afforded by $\mathrm{HGF} / \mathrm{SF}$ aid in releasing such constraints, thus facilitating wound repair by permitting multiple waves of cells encircling the wound to participate in the spreading event. It remains unclear under what conditions, if any, HGF/SF synthesis and release might be upregulated at such sites. Hepatic injury clearly upregulates HGF/SF release as determined by its level in the serum (7). The current findings suggest a potential utility of the HGF/SF signaling pathway in developing new strategies for enhancing the repair of intestinal, and perhaps other, columnar epithelia after injury.

\section{References}

1. Montesano, R., K. Matsumoto, T. Nakamura, and L. Orci. 1991. Identifcation of a fibroblast-derived epithelial morphogen as hepatocyte growth factor. Cell. 67:901-908.

2. Sonnenberg, E., K. M. Weidner, and C. Birchmeier. 1993. Expression of the met-receptor and its ligand scatter factor/hepatocyte growth factor, during mouse development. In Hepatocyte Growth Factor/Scatter Factor and the c-met Receptor. I. D. Goldberg, editor. Birkhäser Verlag AG, Basel, Switzerland. 382394.

3. Stern, C. D., G. W. Ireland, S. E. Herrick, E. Gherardi, J. Gray, M. Peryman, and M. Stoker. 1990. Epithelial scatter factor and development of the chick embryonic axis. Development (Camb.). 110:1271-1284.

4. Wen, D., E. Peles, R. Cupples, S. V. Suggs, S. Bacus, Y. Luo, G. Trail, S. Hu, S. M. Silbiger, B. Levy, et al. 1992. Neu differentiation factor: a transmembrane glycoprotein containing EGF domain and an immunoglobulin homology unit. Cell. 69:559-572.

5. Marsha, M. N., and J. S. Trier. 1974. Morphology and cell proliferation of subepithelial fibroblasts in adult mouse jejunum. I. Structural features. Gastroenterology. 67:607-621.

6. Powell, D. W., and H. M. Berschneider. 1993. Mesenchymal-epithelial interactions: the subepithelial fibroblastic sheath as a paracrine modulator of inflammation-induced intestinal secretion. In Immunophysiology of the Gut. W. A. Walker, P. R. Harmatz, and B. K. Wershil, editors. Academic Press Inc., Orlando, FL. 25-42.

7. Nakamura, T., K. Nawa, and A. Ichihara. 1984. Partial purification and characterization of hepatocyte growth factor from serum of hepatectomized rats. Biochem. Biophys. Res. Comm. 122:1450-1459.

8. Thaler, J., and G. Michalopoulos. 1985. Hepatopoietin A: partial characterization and trypsin activation of a hepatocyte growth factor. Cancer Res. 45:2545-2549.

9. Russell, W. E., J. A. McGowan, and N. R. L. Bucher. 1984. Partial characterization of a hepatocyte growth factor from rat platelets. J. Cell. Physiol. 119:183-192.

10. Miyazawa, K., H. Tsubouchei, D. Naka, K. Takahashi, M. Okigaki, N. Arakaki, H. Nakayama, S. Hirono, O. Sakiyama, K. Takahashi, et al. 1989. Molecular cloning and sequence analysis of cDNA for human hepatocyte growth factor. Biochem. Biophys. Res. Comm. 163:9671-9713.

11. Nakamura, T., T. Nishizawa, M. Hagiya, T. Seki, M. Shimonishi, A. Sugimura, K. Tashiro, and S. Shimizu. 1989. Molecular cloning and expression of human hepatocyte growth factor. Nature (Lond.). 342:440-443.

12. Rosen, E. M., I. D. Goldberg, B. M. Kacinski, T. Buckholz, and D. W. Vinter. 1989. Smooth muscle releases an epithelial cell scatter factor which binds to heparin. In Vitro Cell. \& Dev. Biol. 25:163-173.

13. Stoker, M., and M. Perryman. 1985. An epithelial scatter factor released by embryo fibroblasts. J. Cell Sci. 77:209-213.

14. Weidner, K. M., J. Behrens, J. Vanderkerckhove, and W. Birchmeier. 1990. Scatter factor: molecular characteristics and effect on the invasiveness of epithelial cells. J. Cell Biol. 111:2097-2108.

15. Gherardi, E., and M. Stoker. 1990. Hepatocytes and scatter factor. Nature (Lond.). 346:228.

16. Weidner, K. M., N. Arakaki, G. Hartmann, J. Vandekerckhove, S. Weingart, H. Rieder, C. Fonatasch, H. Tsubouchi, T. Hishida, Y. Daikuhara, and W. Birchmeier. 1991. Evidence for the identity of human scatter factor and human hepatocyte growth factor. Proc. Natl. Acad. Sci. USA. 88:7001-7005.

17. Naldini, L., K. M. Weidner, E. Vigna, G. Gaudino, A. Bardelli, C. Ponzetto, R. P. Narsimhan, G. Hartman, R. Zarnegar, G. K. Michalopoulos, et al. 1991. Scatter factor and hepatocyte growth factor are indistinguishable ligands for the MET receptor. EMBO (Eur. Mol. Biol. Organ.) J. 10:2867-2878.

18. Madara, J. L., and K. Dharmsathaphorn. 1985. Occluding junction structure-function relationships in a cultured epithelial monolayer. J. Cell Biol. 101:2124-2133.

19. Madara, J. L., J. Stafford, K. Dharmsathaphorn, and S. Carlson. 1987. Structural analysis of a human intestinal epithelial cell line. Gastroenterology. 92:1133-1145

20. Dharmsathaphorn, K., K. G. Mandel, J. McRoberts, L. D. Tisdale, and H. Masui. 1984. A human colonic tumor cell line that maintains vectorial electrolyte transport. Am. J. Physiol. 246:6204-6208.

21. Dharmsathaphorn, K., and J. L. Madara. 1990. Established intestinal cell lines as model systems for electrolyte transport studies. Methods Enzymol. 192:354-389.

22. Madara, J. L., S. P. Colgan, A. Nusrat, C. Delp, and C. A. Parkos. 1992. A simple approach to measurement of electrical parameters of cultured epithelial monolayers: use in assessing neutrophil epithelial interactions. Journal Tissue Culture Methods. 14:209-216.

23. Nusrat, A., C. Delp, and J. L. Madara. 1992. Intestinal epithelial restitution. Characterization of a cell culture model and mapping of cytoskeletal elements in migrating cells. J. Clin. Invest. 89:1501-1511.

24. Nash, S., J. Stafford, and J. L. Madara. 1987. Effects of polymorphonuclear leukocyte transmigration on barrier function of cultured intestinal epithelial monolayers. J. Clin. Invest. 80:1104-1113.

25. Madara, J. L., C. Parkos, S. Colgan, R. J. MacLeod, S. Nash, J. Matthews, C. Delp, and W. Lencer. 1992. $\mathrm{Cl}^{-}$secretion in a model intestinal epithelium induced by a neutrophil-derived secretagogue. J. Clin. Invest. 89:1938-1944.

26. Lokker, N. A., M. R. Mark, E. A. Luis, G. L. Bennett, K. A. Robbins, J. B. Baker, and P. J. Godowski. 1992. Structure-function analysis of hepatocyte growth factor: identification of variants that lack mitogenic activity yet retain high affinity receptor binding. EMBO (Eur. Mol. Biol. Organ.) J. 11:2503-2510.

27. Stevenson, B. R., J. M. Anderson, D. A. Goodenough, and M. S. Mooseker. 1988. Tight junction structure and ZO-1 content are identical in two strains of Madin-Darby canine kidney cells which differ in transepithelial resistance. J. Cell Biol. 107:2401-2408.

28. Le Bivic, A., X. R. Francisco, and E. Rodriguez-Boulan. 1989. Vectorial targeting of apical and basolateral plasma membrane protein in a human adenocarcinoma epithelial cell line. Proc. Natl. Acad. Sci. 86:9313-9317.

29. Kaoutzani, P., C. A. Parkos, C. Delp-Archer, and J. L. Madara. 1993. Isolation of plasma membrane fractions from the intestinal epithelial model T84. Am. J. Physiol. (Cell Physiol.) In press. 
30. Rosen, E. M., L. Meromsky, E. Setter, D. W. Vinter, and I. D. Goldberg. 1990. Purification and migration-stimulating activities of scatter factor. Proc. Soc. Exp. Biol. Med. 195:34-43.

31. Parkos, C. A., S. P. Colgan, C. Delp, M. A. Arnaout, and J. L. Madara. 1992. Neutrophil migration across a cultured epithelial monolayer elicits a biphasic resistance response representing sequential effects on transcellular and paracellular pathways. J. Cell Biol. 117:757-764.

32. Tice, L. W., R. L. Carter, and M. B. Cahill. 1979. Changes in tight junctions of rat intestinal crypt cells associated with changes in their mitotic activity. Tissue \& Cell. 11:293-316.

33. Frizzell, R. A., M. Field, and S. G. Schultz. 1979. Sodium-coupled chloride transport by epithelial tissues. Am. J. Physiol. 236:F1-F8.

34. Powell, D. 1981. Barrier function of epithelia. Am. J. Physiol. 241:G275G288.

35. Welsh, M. J., P. L. Smith, and R. A. Frizzell. 1983. Chloride secretion by canine tracheal epithelium. III. Membrane resistance and electromotive forces. $J$. Membr. Biol. 71:209-218.

36. Venglarik, C. J., R. J. Bridges, and R. A. Frizzell. 1990. A simple assay for agonist-regulated $\mathrm{Cl}$ and $\mathrm{K}$ conductances in salt-secreting epithelial cells. $\mathrm{Am}$. J. Physiol. 259:C358-C362.

37. Gumbiner, B., and K. Simons. 1986. A functional assay for proteins involved in establishing an epithelial occluding barrier. Identification of a uvomorulin-like polypeptide. J. Cell Biol. 102:457-468.

38. Imhof, B. A., P. Vollmers, S. L. Goodman, and W. Birchmeier. 1983. Cell-cell interaction and polarity of epithelial cells: specific perturbation using a monoclonal antibody. Cell. 35:667-675.

39. Feil, W., E. Wenzl, P. Vattay, M. Starlinger, T. Sogukoglu, and R. Schiessel. 1987. Repair of rabbit duodenal mucosa after acid injury in vivo and in vitro. Gastroenterology. 92:1973-1986.

40. Moore, R., S. Carlson, and J. L. Madara. 1989. Rapid barrier restitution in an in vitro model of intestinal epithelial injury. Lab. Invest. 60:237-244.
41. Stoker, M., E. Gherardi, M. Perryman, and J. Gray. 1987. Scatter factor is a fibroblast derived modulator of epithelial cell mobility. Nature (Lond.). 327:239-241.

42. Stoker, M., and E. Gherardi. 1989. Scatter factor and other regulators of cell mobility. Br. Med. Bull. 45:481-491.

43. McNeill, H., M. Ozawa, R. Kemler, and W. J. Nelson. 1990. Novel function of the cell adhesion molecule uvomorulin as an inducer of cell surface polarity. Cell. 62:309-316.

44. Ozawa, M., and R. Kemler. 1992. Molecular organization of the uvomorulin-catenin complex. J. Cell Biol. 116:989-996.

45. Naldini, L., E. Vigna, R. Ferracini, P. Longati, L. Gandino, M. Prat, and P. M. Comoglio. 1991. The tyrosine kinase encoded by the MET proto-oncogene is activated by autophosphorylation. Mol. Cell. Biol. 11:1793-1803.

46. Tsarfaty, I., J. H. Resau, S. Rulong, I. Keydar, D. L. Faletto, and G. F. Vande Woude. 1992. The met proto-oncogene receptor and lumen formation. Science (Wash. DC). 257:1258-1261.

47. Sonnenberg, E., D. Meyer, K. M. Weidner, and C. Birchmeier. 1993. Scatter factor/hepatocyte growth factor and its receptor, the c-met tyrosine kinase, can mediate a signal exchange between mesenchyme and epithelia during mouse development. J. Cell Biol. 123:223-235.

48. Rutten, M. J., and S. Ito. 1983. Morphology and electrophysiology of guinea pig gastric mucosal repair in vitro. Am. J. Physiol. 244:G171-G182.

49. Bement, W. M., P. Forscher, and M. S. Mooseker. 1993. A novel cytoskeletal structure involved in purse string wound closure and cell polarity maintenance. J. Cell Biol. 121:565-578.

50. Omann, G. M., R. A. Allen, G. M. Bokoch, R. G. Painter, A. E. Traynor, and L. A. Sklar. 1987. Signal transduction and cytoskeletal activation in the neutrophil. Physiol. Rev. 67:285-322.

51. Singer, S. J., and A. Kupfer. 1986. The directed migration of eukaryotic cells. Annu. Rev. Cell Biol. 2:337-365. 